\title{
SERUM HOMOCYSTEINE LEVELS IN CZECH CHILDREN AND ADOLESCENTS
}

\author{
Vladimír Němec, Eva Bočkayová, Štěpán Kutílek
}

Pardubice Hospital and Faculty of Health Studies, University of Pardubice, Pardubice, Czech Republic: Department of Pediatrics

Summary: Aim: The principal aim was to establish reference paediatric data for the serum homocysteine levels in Czech children and adolescents. Methods and Results: 144 children either healthy or not sufferig from acute or chronic inflammation, autoimmune disorders including rheumatic diseases, inflammatory musculoskeletal disorders, inflammatory bowel disease, diabetes mellitus, hypercholesterolemia, epilepsy, chronic renal failure, aged 0-19.9 years (0-6.9 years, $\mathrm{n}=40 ; 7-10.9 \mathrm{y}, \mathrm{n}=28 ; 11-15.9 \mathrm{y}, \mathrm{n}=45 ; 16-19.9 \mathrm{y}, \mathrm{n}=31)$ had their blood samples collected and the serum homocysteine level (S-homocysteine) was evaluated by chemiluminescence. A significant age dependence of the S-homocysteine levels was observed $(\mathrm{R}=0.35, \mathrm{p}<0.01)$; with highest values of upper reference range in the 11-15.9 and 16-19.9 years' group, respectively. Conclusion: The establishment of S-homocysteine reference Czech pediatric values is a potentially useful tool for proper evaluation of elevated homocysteine levels and corresponding risks in childhood.

Key words: S-homocysteine; Reference values; Children

\section{Introduction}

Homocysteine is an amino acid that is homologous to cysteine, the only difference being additional methylene (-CH2-) group. Its formula is $\mathrm{HSCH}_{2} \mathrm{CH}_{2} \mathrm{CH}\left(\mathrm{NH}_{2}\right) \mathrm{CO}_{2} \mathrm{H}$. Homocysteine is biosynthesized from methionine by the removal of its terminal $\mathrm{C}$ methyl group. Homocysteine can be recycled into methionine or converted into cysteine with the aid of B-vitamins. Deficiencies of the vitamins B6, B9, and B12 can lead to high serum homocysteine (S-homocysteine) concentration $(11,14,15,19,23)$. The serum homocysteine level (S-homocysteine) is inversely correlated with serum folate concentration in children and adults $(12,14,15,17,19,20,28)$. High S-homocysteine has been linked to cardiovascular and neurodegenerative disease, diabetes, thrombosis $(8,20,23)$. Hyperhomocysteinemia is associated with alterations in vascular morphology, loss of endothelial anti-thrombotic function, and induction of a procoagulant environment. Most known forms of damage or injury are due to homocysteine-mediated oxidative stress (23). S-homocysteine levels in adults in industrialized countries are in the range of $10-15 \mu \mathrm{mol} / \mathrm{L}$, while in developing countries the upper reference range can reach even $20 \mu \mathrm{mol} / \mathrm{L}$, most probably as a result of vitamin B deficiency (29). Generally, the S-homocysteine levels are higher in males than in females $(4,12,13,18,20,24)$. In children and adolescents, S-homocysteine levels range from 3 to $10 \mu \mathrm{mol} / \mathrm{L}$ $(1-7,9-22,24-30)$. Due to the fact that the serum homocysteine levels are age-dependent in both children and adults $(9,13,18-22,24,29,30)$, establishment of proper pediatric reference values is necessary. The aim of our study was to establish physiologic reference values of the S-homocysteine levels in Czech children and adolescents aged $0-19.9$ years.

\section{Materials and Methods}

144 children (68 boys and 76 girls) aged 0 month through 19.9 years (mean $10.3 \mathrm{y} \pm 5.4 \mathrm{SD}$ ) were enrolled. The children were sorted into 4 age groups (Table 1). The children were either healthy; or did not suffer from acute or chronic inflammation, autoimmune disorders including rheumatic diseases, inflammatory musculoskeletal disorders, inflammatory bowel disease, diabetes mellitus, hypercholesterolemia, epilepsy, chronic renal failure. All children had a negative personal history of thrombosis and/or thromboembolism. All were on a standard central European diet, consisting mostly of meat and carbohydrates. None was on a diet poor in vitamin B, nor was receiving doses of vitamin $\mathrm{B}$ exceeding recommended daily allowances. S-homocysteine level was evaluated by chemiluminescence (Immulite 2500 immunoassay system, Siemens Healthcare Diagnostics, Germany) and expressed in $\mu \mathrm{mol} / \mathrm{L}$. The interassay variation was $2.06 \%$ in samples with S-homocysteine concentration $7.43 \mu \mathrm{mol} / \mathrm{L} ; 1.99 \%$ with S-homocysteine $10.31 \mu \mathrm{mol} / \mathrm{L}$, and $1.72 \%$ with S-homocysteine $22.25 \mu \mathrm{mol} / \mathrm{L}$, respectively. 
Tab. 1: S-homocysteine values in children

\begin{tabular}{|c|c|c|c|c|}
\hline Age (years) & $\mathrm{N}$ & $\begin{array}{c}\text { mean } \\
\text { S-homocysteine } \\
(\mu \mathrm{mol} / \mathrm{L})\end{array}$ & $\mathrm{SD}$ & $\begin{array}{c}\text { Reference } \\
\text { range } \\
(\mu \mathrm{mol} / \mathrm{L})\end{array}$ \\
\hline $0-6.9$ & 40 & 6.5 & 1.9 & $2.7-10.3$ \\
\hline $7.0-10.9$ & 28 & 7.4 & 2.0 & $3.4-11.4$ \\
\hline $11.0-15.9$ & 45 & 8.3 & 2.2 & $3.9-12.7$ \\
\hline $16.0-19.9$ & 31 & 8.3 & 1.9 & $4.5-12.1$ \\
\hline
\end{tabular}

For statistical analysis, Sigmaplot 2.0 and Systat programme was used. The mean values and standard deviations (SD) were calculated. Unpaired t-test was used to calculate gender-related differences and ANOVA was used to assess differences among different age groups. Correlation analysis was performed to compare the relationship between age and S-homocysteine level. For all results, $\mathrm{p}<0.05$ was required for statistical significance.

\section{Results}

The mean S-homocysteine value in the entire group of 144 children was $7.6 \mu \mathrm{mol} / \mathrm{L} \pm 2.1$ (SD). The obtained values sorted by age are expressed in Table 1 . The S-homocysteine values were highest in the 11.0-15.9 y and 16.0-19.9 y group, respectively. The data were distributed homogenously.

The S-homocysteine levels were significantly different between the 0-6.9 y age-group and the 11.0-15.9 y and $16.0-19.9$ y age-groups $(\mathrm{p}=0.0003$ and 0.0002 , respectively). The differences between the 7.0-10.9 y group and the

$\mathrm{R}=0.35$

$\mathrm{p}<0.01$

S-homocysteine

$(\mu \mathrm{mol} / \mathrm{L})$

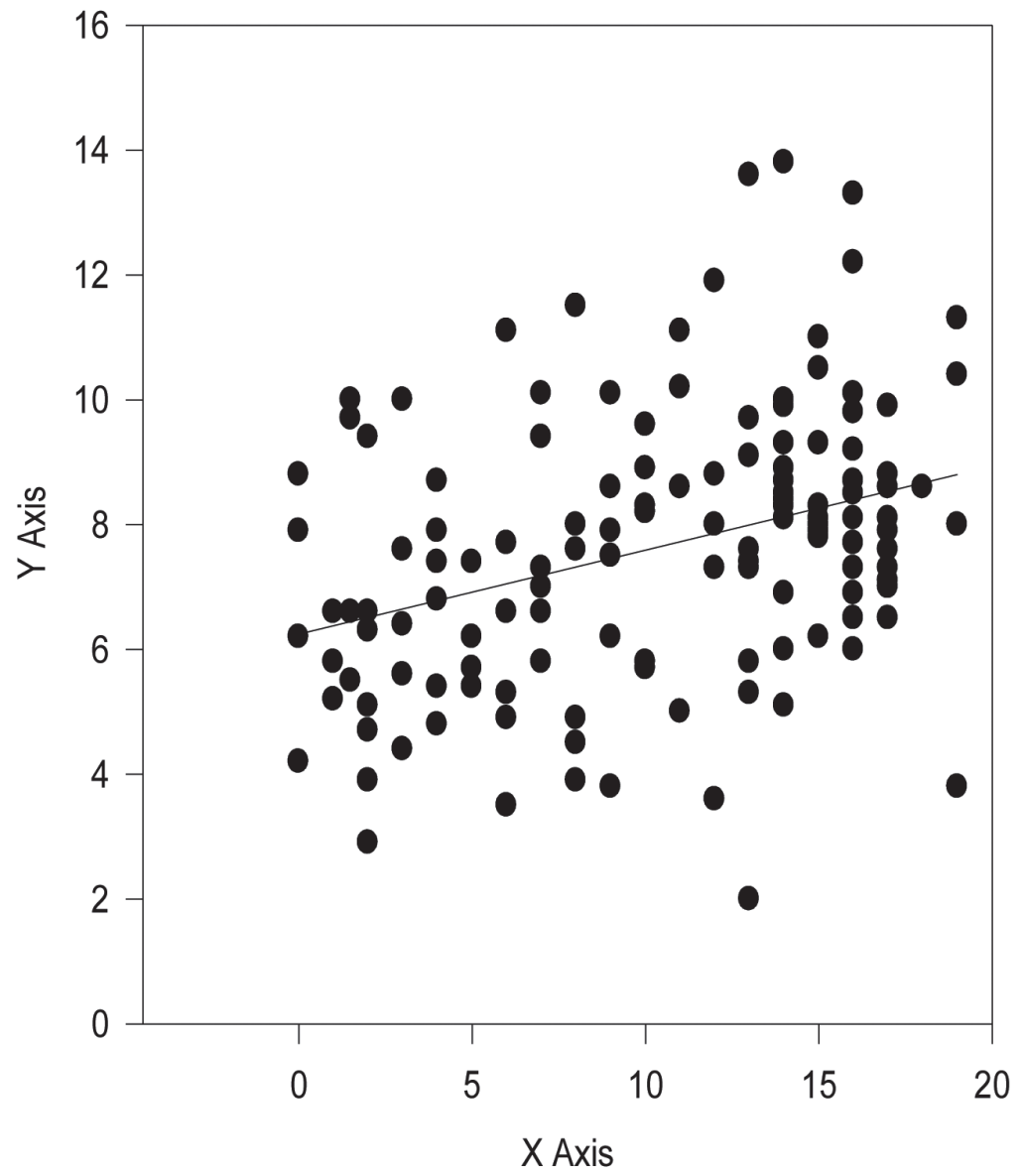

Age (years)

Fig. 1: S-homocysteine related to age 
$11.0-15.9$ y and $16.0-19.9$ y age groups did not reach statistical significance ( $p=0.08$ and 0.06 respectively), same as the difference between the $0-6.9$ y and $7.0-10.9$ y group $(\mathrm{p}=0.09)$. There was no difference between 11.0-15.9 $\mathrm{y}$ and $16.0-19.9$ y group $(p=0.88)$. The S-homocysteine levels did not differ between boys $(7.5 \mu \mathrm{mol} / \mathrm{L} \pm 1.7 \mathrm{SD})$ and girls $(7.7 \mu \mathrm{mol} / \mathrm{L} \pm 1.9 \mathrm{SD})(\mathrm{p}=0.60)$, neither were there any gender related differences within the respective age-groups. There was a significant correlation between S-homocysteine values and age $(\mathrm{r}=0.35, \mathrm{p}<0.01)$ (Fig. 1).

\section{Discussion}

Our results represent data from paediatric population inclusive of neonates and infants, and shows strong agedependence of the serum homocysteine (Table 1, Figure 1). These results suggest age-dependent increase in S-homocysteine with no gender related differences. Previously published papers regarding the paediatric S-homocysteine levels from different countries varied in subject numbers and age.

The majority of published results revealed values of S-homocysteine closely similar to ours.

A 1997 Spanish study (28) comprised of 195 healthy subjects (112 males and 83 females; aged 2 months 18 years). The median values of S-homocysteine were $6.3 \mu \mathrm{mol} / \mathrm{L}$ and the 2.5 and 97.5 percentiles were 3.7-10.3 $\mu \mathrm{mol} / \mathrm{L}$. S-homocysteine levels were independent of sex and in subjects $14-18$ years old $(n=56)$ the medians were $7.8 \mu \mathrm{mol} / \mathrm{L}(5.2-11.3)$ for boys $(\mathrm{n}=24)$ and $7.4 \mu \mathrm{mol} / \mathrm{L}(4.7-10.8)$ for girls $(\mathrm{n}=32)$, respectively. The gender difference was not statistically significant. The S-homocysteine increased significantly with age $(\mathrm{r}=0.56 ; \mathrm{n}=195 ; \mathrm{p}<0.001)$. There were three age groups with S-homocysteine being significantly different from one another $(\mathrm{p}<0.001)$ : 2 month-10 years $(\mathrm{n}=105$; median $5.8 \mu \mathrm{mol} / \mathrm{L}$; interval $3.3-8.3), 11-15$ years $(\mathrm{n}=59$; median $6.6 \mu \mathrm{mol} / \mathrm{L}$; interval $4.7-10.3)$, and $16-18$ years $(\mathrm{n}=31$; median $8.1 \mu \mathrm{mol} / \mathrm{L}$; interval 4.7-11.3) (28).

In a study from Canada, 29 children with chronic renal failure had their S-homocysteine values compared with healthy controls $(\mathrm{n}=57)$. The controls' mean S-homocysteine concentration was $6.8 \mu \mathrm{mol} / \mathrm{L}$, and the $95 \mathrm{th}$ percentile for controls was $14.0 \mu \mathrm{mol} / \mathrm{L}$ (15).

In a Greek study (17), the S-homocysteine levels measured in 524 children ( 275 boys and 249 girls) aged $6-15$ years old resulted in a geometric mean of $7.8 \mu \mathrm{mol} / \mathrm{L}$ for boys and $7.5 \mu \mathrm{mol} / \mathrm{L}$ for girls, respectively. The geometric mean $\mathrm{S}$-homocysteine level was significantly $(\mathrm{P}<0.001)$ increasing with age; $6.4 \mu \mathrm{mol} / \mathrm{L}$ was found in the age group of 6-9 years, $7.2 \mu \mathrm{mol} / \mathrm{L}$ in the $10-12$ years' group, and $8.5 \mu \mathrm{mol} / \mathrm{L}$ in the $13-15$ years' group (17).

Dutch study (27) comprised of a sample of 234 children aged $0-19$ years. The geometric mean S-homocysteine concentrations were 5.1, 4.6, 6.2, 7.3 and $8.7 \mu \mathrm{mol} / \mathrm{L}$ in the $0-1$, $2-5,6-10,11-14$, and 15-19 year groups, respectively.
A study performed by Tonstand et al in Norway evaluated S-homocysteine in 678 children aged 8-12 years with a geometric mean of $5.25 \mu \mathrm{mol} / \mathrm{L}$ (26).

A Belgian study involving 178 children aged 5-9 years revealed mean S-homocysteine level of $6.21 \mu \mathrm{mol} / \mathrm{L}$ (7).

British study included 51 children (age range 4-6.99 years) and 131 children (age range 7-10.99 years) with geometric means of S-homocysteine levels 5.16 and $5.59 \mu \mathrm{mol} / \mathrm{L}$, respectively (5).

In a recent Turkish study, plasma total homocysteine levels were measured in 2257 Turkish individuals (1381 men and 876 women) aged 1-90 years. In children and adolescents the mean plasma total homocysteine levels for the 1-10 and 11-20 age groups, were 6.5 and $9.6 \mu \mathrm{mol} / \mathrm{L}$ for males and 7.1 and $7.6 \mu \mathrm{mol} / \mathrm{L}$ in females, respectively. Plasma total homocysteine levels were increasing with age and men were found to have higher levels than women (30).

In a study from Nigeria (1), the mean S-homocysteine levels in a population of 182 subjects aged 10-19 years were lower than those in our study: $2.7 \pm 2.4,3.5 \pm 3.2$ and 3.6 $\pm 3.2,4.1 \pm 3.6 \mu \mathrm{mol} / \mathrm{L}$ for the girls and boys aged 10-14 and 15-19 years, respectively (1). However the standard deviations were higher and the upper reference ranges were therefore similar to our results.

The results of two studies conducted in the US are of particular interest $(10,16)$ : In 343 children aged 5-8 years, the S-homocysteine geometric mean was $5.7 \mu \mathrm{mol} / \mathrm{L}$ (10).

In another US study, children aged 4-5 years participated; the study population was non-Hispanic Caucasian $(\mathrm{n}=73)$, non-Hispanic African-American $(\mathrm{n}=99)$, and Mexican-American $(\mathrm{n}=105)$, with reported geometric means of 4.4, 4.7, and $4.3 \mu \mathrm{mol} / \mathrm{L}$, respectively (16).

In an Iranian study, 402 subjects (201 healthy males and 201 healthy females aged $>15$ years) were randomly selected. The mean plasma homocysteine level was significantly higher in men $(7.3 \mu \mathrm{mol} / \mathrm{L})$ than in women $(6.3 \mu \mathrm{mol} / \mathrm{l}$; $\mathrm{P}<0.001)$. The geometric mean levels for ages 15-25 years were $5.9 \mu \mathrm{mol} / \mathrm{L}$ in women and $7.5 \mu \mathrm{mol} / \mathrm{L}$ in men, respectively (9).

Some results from developing countries reveal mostly higher values of S-homocysteine than those obtained by us.

In a study from Brazil with 63 children aged $1-8$ years, S-homocysteine mean value was $8.65 \mu \mathrm{mol} / \mathrm{L}$ (2).

In Indian children and adolescents $(n=103)$ aged 10-19 years, the mean S-homocysteine level was $11.6 \pm$ $0.4 \mu \mathrm{mol} / \mathrm{L} \mathrm{(3).}$

A study from Guatemala included 180 children 8-12 years of age, with S-homocysteine mean level of $9.24 \mu \mathrm{mol} / \mathrm{L} ; 9 \%$ of participants had S-homocysteine above $12.0 \mu \mathrm{mol} / \mathrm{L}(21)$.

A recent Mexican study included 56 healthy children aged 2-10 years; the total homocysteine level was $9.78 \pm$ $1.73 \mu \mathrm{mol} / \mathrm{L}$ (mean $\pm \mathrm{SD})$. Contrary to other observations, the homocysteine levels were decreasing with age: $10.49 \pm 1.92 \mu \mathrm{mol} / \mathrm{L}$ in the $2.0-3.99$ years' group, $9.78 \pm$ $1.67 \mu \mathrm{mol} / \mathrm{L}$ in the $4.0-6.99$ years' group and $8.67 \pm$ 
$1.60 \mu \mathrm{mol} / \mathrm{L}$ in the $7-10$ years' group. This was ascribed to vitamin B deficiency (6).

Our results are very similar to the ones obtained from other paediatric and adolescent populations from various countries with different ethnical, cultural and nutritional background. Concerning our results, there is not a great interindividual variability of those values in children, as reflected by the standard deviation. Such an observation is further strongly in favour of establishing reference paediatric data, as the reproducibility of results should be considered as reliable, especially when taking into consideration the small interindividual variability of serum homocysteine reference values. Our results are in accordance with most of the previously published data, especially in terms of the age-dependency of serum homocysteine levels.

In conclusion, we present the serum homocysteine paediatric reference values suitable for Czech children and adolescents aged 0-19 years. We consider the establishment of serum homocysteine reference paediatric values a potentially useful tool for proper evaluation of elevated homocysteine levels and corresponding risks in childhood.

\section{References}

1. Adebayo KJ, Madu EF, Adebayo-Kay VC. Serum total homocysteine concentrations in children and adolescents in Jos, Nigeria. J Trop Pediatr. 2008; 54: 282-3

2. Aléssio AC, Annichino-Bizzacchi JM, Bydlowski SP, Eberlin MN, Vellasco AP, Höehr NF. Polymorphisms in the methylenetetrahydrofolate reductase and methionine synthase reductase genes and homocysteine levels in Brazilian children. Am J Med Genet 2004; A 3: 256-60.

3. Anand P, Awasthi S, Mahdi A, Tiwari M, Agarwal GG. Serum homocysteine in Indian adolescents. Indian J Pediatr. 2009; 76: 705-9.

4. Angelova EA, Minkova GD, Atanasova PA, Semerdjieva MA, Tzvetkova TZ. A study of plasma total homocysteine levels in healthy people. Folia Med (Plovdiv). $2005 ; 47: 53-8$.

5. Bates CJ, Mansoor MA, Gregory J, Pentiev K, Prentice A. Correlates of plasma homocysteine, cysteine and cysteinylglycine in respondents in the British National Diet and Nutrition Survey of young people aged 4-18 years, and a comparison with the survey of people aged 65 years and over. Br J Nutr 2002; 87: 71-9.

6. Dávila-Rodríguez MI, Torres-De la Cruz VM, Novelo-Huerta HI, Said-Fernández S, Cerda-Flores RM, Cortés-Gutiérrez EI. Total homocysteine levels in healthy children from the Monterrey Metropolitan Area, Mexico. Prague Med Rep. 2010; 111: 135-41.

7. De Laet C, Wautrecht JC, Brasseur D, Dramaix M, Boeynaems JM, Decuyper J, Kahn A. Plasma homocysteine concentrations in a Belgian school-age population. Am J Clin Nutr 1999; 69: 968-72.

8. Geisel J, Hübner U, Bodis M, Schorr H, Knapp JP, Obeid R, Herrmann W. The role of genetic factors in the development of hyperhomocysteinemia. Clin Chem Lab Med. 2003; 41: 1427-34.

9. Golbahar J, Rezaian G, Bararpour H. Distribution of plasma total homocysteine concentrations in the healthy Iranians. Clin Biochem. 2004; 37: 149-51.

10. Greenlund KJ, Srinivasan SR, Xu J, Dalferes E Jr, Myers L, Pickoff A, Berenson GS. Plasma homocysteine distribution and its association with parental history of coronary artery disease in black and white children. Circulation 1999; 99: 2144-9.
11. Hanumante NM, Wadia RS, Deshpande SS, Sanwalka NJ, Vaidya MV, Khadilkar AV. Vitamin B12 and homocysteine status in asymptomatic Indian toddlers. Indian J Pediatr. 2008; 75: 751-3.

12. Henríquez P, Doreste J, Deulofeu R, Fiuza MD, Serra-Majem L. Nutritional determinants of plasma total homocysteine distribution in the Canary Islands. Eur J Clin Nutr. 2007; 61: 111-8.

13. Leowattana W, Bhuripanyo K, Mahanonda N, Pokum S. Prevalence of hyperhomocysteinemia in normal healthy Thai subjects. J Med Assoc Thai. 2001; 84, Suppl 3: S722-9.

14. Mainou Cid C, García Giralt N, Vilaseca Buscà MA, Ferrer Codina I, Meco López JF, Mainou Pintó A, Pintó Sala X, Grinberg Vaisman D, Balcells Comas S. Hyperhomocystinemia and $677 \mathrm{C} \mathrm{T}$ methylenetetrahydrofolate reductase polymorphism as a cardiovascular risk factor in childhood. An Esp Pediatr. 2002; 56: 402-8.

15. Merouani A, Lambert M, Delvin EE, Genest J Jr, Robitaille P, Rozen R. Plasma homocysteine concentration in children with chronic renal failure. Pediatr Nephrol. $2001 ; 16: 805-11$.

16. Must A, Jacques PF, Rogers G, Rosenberg IH. Serum total homocysteine concentrations in children and adolescents: results from the third National Health and Nutrition Examination Survey (NHANES III). J Nutr 2003; 133: 2643-9.

17. Papandreou D, Mavromichalis I, Makedou A, Rousso I, Arvanitidou M. Total serum homocysteine, folate and vitamin B12 in a Greek school age population. Clin Nutr. 2006; 25: 797-802.

18. Pijoán Zubizarreta JI, Irigoien Garbizu I, Aguirre Errasti C. Population reference ranges and determinants of plasma homocysteine levels. Med Clin (Barc). 2001; 117: 487-91.

19. Rauh M, Verwied S, Knerr I, Dörr HG, Sönnichsen A, Koletzko B. Homocysteine concentrations in a German cohort of 500 individuals: reference ranges and determinants of plasma levels in healthy children and their parents. Amino Acids. 2001; 20: 409-18.

20. Riddell LJ, Chisholm A, Duncan A, Mann JI. Homocysteine levels in healthy New Zealanders and those with vascular disease. N Z Med J. 1999; 112: 438-42.

21. Rogers LM, Boy E, Miller JW, Green R, Sabel JC, Allen LH. High prevalence of cobalamin deficiency in Guatemalan schoolchildren: associations with low plasma holotranscobalamin II and elevated serum methylmalonic acid and plasma homocysteine concentrations. Am J Clin Nutr 2003; 2: 433-40.

22. Rossi E, Beilby JP, McQuillan BM, Hung J. Biological variability and reference intervals for total plasma homocysteine. Ann Clin Biochem. 1999; 36: 56-61.

23. Stanger O, Herrmann W, Pietrzik K, Fowler B, Geisel J, Dierkes J, Weger M, DACH-LIGA Homocystein e.V. DACH-LIGA homocystein (German, Austrian and Swiss homocysteine society): Consensus paper on the rational clinical use of homocysteine, folic acid and B-vitamins in cardiovascular and thrombotic diseases: guidelines and recommendations. Clin Chem Lab Med. 2003; 41: 1392-403.

24. Taskin G, Yilmaz Sipahi E, Yildirimkaya M, Nadirler F, Halloran M, Ayoglu FN, Laleli Y. Plasma total homocysteine levels in a healthy Turkish population sample. Acta Cardiol. 2006; 61: 35-42.

25. Thomas NE, Cooper SM, Baker JS, Graham MR, Davies B. Homocyst(e)ine, folate, and vitamin B12 status in a cohort of Welsh young people aged 12-13 years old. Res Sports Med. 2008; 16: 233-43.

26. Tostand S, Refsum H, Sivertsen M, Christophersen B, Ose L, Ueland PM Relation of total homocysteine and lipid levels in children to premature cardiovascular death in male relatives. Pediatr Res 1996; 40, 47-52.

27. van Beynum IM, den Heijer M, Thomas CM, Afman L, Oppenraay-van Emmerzaal D, Blom HJ. Total homocysteine and its predictors in Dutch children. Am J Clin Nutr. 2005; 81: 1110-6.

28. Vilaseca MA, Moyano D, Ferrer I, Artuch R. Total homocysteine in pediatric patients. Clin Chemistry 1997; 43: 690-2.

29. Wang W, Zhao D, Liu J, Liu J, Zhang Z, Liu J, Liu S, Lin Z, Wu Z. The distribution of serum homocysteine and its associated factors in a population of 1168 subjects in Beijing area. Zhonghua Liu Xing Bing Xue Za Zhi. 2002; 23: 32-5.

30. Yaman H, Akgul EO, Kurt YG, Cakir E, Gocgeldi E, Kunak ZI, Macit E, Cayci T, Erbil MK. Plasma total homocysteine concentrations in a Turkish population sample. Acta Cardiol. 2009; 64: 247-51.

Received: 01/08/2011

Accepted in revised form: 01/02/2012

\section{Correspondence:}

Štěpán Kutílek, MD, PhD, Department of Pediatrics, Pardubice Hospital and Faculty of Health Studies, University of Pardubice, Kyjevská 44, 53203 Pardubice ,Czech Republic; e-mail: stepan.kutilek@nemocnice-pardubice.cz 